\title{
Propolis, a Constituent of Honey, Inhibits the Development of Sugar Cataracts and High-Glucose-Induced Reactive Oxygen Species in Rat Lenses
}

\author{
Teppei Shibata, ${ }^{1}$ Shinsuke Shibata, ${ }^{1}$ Naoko Shibata, ${ }^{1}$ Etsuko Kiyokawa, ${ }^{2}$ \\ Hiroshi Sasaki, ${ }^{1}$ Dhirendra P. Singh, ${ }^{3}$ and Eri Kubo ${ }^{1}$ \\ ${ }^{1}$ Department of Ophthalmology, Kanazawa Medical University, Ishikawa 920-0293, Japan \\ ${ }^{2}$ Department of Oncogenic Pathology, Kanazawa Medical University, Ishikawa 920-0293, Japan \\ ${ }^{3}$ Department of Ophthalmology and Visual Sciences, University of Nebraska Medical Center, Omaha, NE 68198-5540, USA \\ Correspondence should be addressed to Eri Kubo; kuboe@kanazawa-med.ac.jp
}

Received 4 March 2016; Accepted 19 April 2016

Academic Editor: Jesús Pintor

Copyright (C) 2016 Teppei Shibata et al. This is an open access article distributed under the Creative Commons Attribution License, which permits unrestricted use, distribution, and reproduction in any medium, provided the original work is properly cited.

Purpose. This study investigated the effects of oral propolis on the progression of galactose-induced sugar cataracts in rats and the in vitro effects of propolis on high-glucose-induced reactive oxygen species (ROS) and cell death in cultured rat lens cells (RLECs). Methods. Galactose-fed rats and RLECs cultured in high glucose $(55 \mathrm{mM})$ medium were treated with propolis or vehicle control. Relative lens opacity was assessed by densitometry and changes in lens morphology by histochemical analysis. Intracellular ROS levels and cell viability were measured. Results. Oral administration of propolis significantly inhibited the onset and progression of cataract in $15 \%$ and $25 \%$ of galactose-fed rats, respectively. RLECs cultured with high glucose showed a significant increase in ROS expression with reduced cell viability. Treatment of these RLECs with 5 and $50 \mu \mathrm{g} / \mathrm{mL}$ propolis cultured significantly reduced ROS levels and increased cell viability, indicating that the antioxidant activity of propolis protected cells against ROS-induced damage. Conclusion. Propolis significantly inhibited the onset and progression of sugar cataract in rats and mitigated high-glucoseinduced ROS production and cell death. These effects may be associated with the ability of propolis to inhibit hyperglycemia-evoked oxidative or osmotic stress-induced cellular insults.

\section{Introduction}

Hyperglycemia is the major factor in the development of diabetic cataracts. Hyperglycemia activates the aldose reductase (AR)/sorbitol (polyol) pathway and induces osmotic and/ or oxidative stress [1-6]. AR converts aldose sugars, such as glucose and galactose, to polyols in the presence of reduced nicotinamide-adenine dinucleotide phosphate (NADPH), which is abundant in lens fibers $[3,7]$. In the lens, osmotic stress induced by sorbitol accumulation is regarded as the major factor in the progression of diabetic cataract $[1-3,8,9]$. Activation of the polyol pathway also increases oxidative stress by increasing levels of hydrogen peroxide [10] and free radicals [11].

Hyperglycemia-induced oxidative stress has been shown to be a major culprit in the development and progression of galactose-associated cataracts, a process inhibited by antioxidants and AR inhibitors (ARI) [11]. Increased osmotic stress associated with activation of the polyol pathway can induce endoplasmic reticulum stress, generating reactive oxygen species (ROS), which in turn induce cell damage [12]. Hyperglycemia associated ROS are generated by the autoxidation of glucose, the nonenzymatic glycation of proteins, the glucoseinduced activation of protein kinase $\mathrm{C}$, increased polyol pathway activity, and impairment of antioxidant enzymes and alterations in mitochondria [13-17]. Taken together, these findings suggested that oxidative stress induced by osmotic stress and hyperglycemia is a major factor in the etiology of cell death signaling that finally leads to cataractogenesis.

Recently, considerable effort has sought to identify therapeutic agents, including those of phytochemical origin, which can promote naturally occurring cellular antioxidant defense 
systems. Propolis is a component of honey collected by bees from tree buds and widely available as a dietary supplement. Propolis and caffeic acid phenethyl ester (CAPE), an active component of propolis extract, have been shown to have immunomodulatory, antitumor, cytotoxic, antimetastatic, anti-inflammatory, and antioxidant properties [18]. Moreover, propolis has been shown to normalize glucose homeostasis in animal models of type 2 diabetes $[19,20]$.

However, propolis contents and activity have been associated with specific plant sources, collecting location and phytogeographic areas. Several studies have investigated the activity against various disorders, including hyperglycemia, of propolis obtained from different geographical regions. To date, however, the ability of propolis to delay or inhibit sugar or oxidative stress-induced cataract formation has not been investigated. This study therefore examined the in vivo effect of orally administered green Brazilian propolis on the development of galactose-induced cataract in rats and the in vitro effects of propolis on high-glucose-induced ROS levels and cell viability in cultured rat lens epithelial cells (RLECs). The results of this study may contribute to the development of strategies to prevent or delay hyperglycemia-induced complications.

\section{Materials and Methods}

2.1. Cell Culture. RLECs isolated from SD rats were cultured in Dulbecco's modified eagle medium (DMEM; Sigma, St. Louis, MO, USA), supplemented with $20 \%$ fetal bovine serum (FBS; Sigma) at $37^{\circ} \mathrm{C}$ in an air $/ \mathrm{CO}_{2}(19: 1)$ atmosphere. At passages $8-10$, the medium was replaced by serum-free medium containing $50 \mu \mathrm{g} / \mathrm{mL}$ purified honey or 5 or $50 \mu \mathrm{g} / \mathrm{mL}$ propolis and cultured for $12 \mathrm{hrs}$. The cells were subsequently cultured for $120 \mathrm{hrs}$ in high glucose medium, consisting of DMEM, 5\% FBS, and $5.5 \mathrm{mM}$ or $55 \mathrm{mM}$ D-glucose (Sigma) or, as osmotic control, $55 \mathrm{mM}$ D-mannitol (Sigma) and with $50 \mu \mathrm{g} / \mathrm{mL}$ purified honey or 5 or $50 \mu \mathrm{g} / \mathrm{mL}$ propolis.

2.2. Quantitation of Intracellular ROS. Intracellular ROS level was measured using the fluorescent dye, dichlorofluorescein diacetate (H2-DCF-DA), and a nonpolar compound converted to a polar derivative (dichlorofluorescein) by cellular esterase after incorporation into cells [21]. RLECs $\left(5 \times 10^{3}\right)$ were cultured in 96-well plates for $120 \mathrm{hrs}$ with DMEM and 5\% FBS; $5.5 \mathrm{mM}$, $55 \mathrm{mM}$ D-glucose, or $55 \mathrm{mM}$ D-mannitol; and $50 \mu \mathrm{g} / \mathrm{mL}$ purified honey or 5 or $50 \mu \mathrm{g} / \mathrm{mL}$ propolis.

The medium was replaced with Hank's solution (Sigma) containing $10 \mu \mathrm{M}$ DCFH-DA (Cayman Chemical, Ann Arbor, MI) and incubated for $10 \mathrm{~min}$ at room temperature. Intracellular fluorescence was detected at an excitation wavelength of $485 \mathrm{~nm}$ and an emission wavelength of $530 \mathrm{~nm}$ using Spectra Max Gemini EM (Molecular Devices, Sunnyvale, CA).

2.3. Cell Viability Assay (MTS Assay). Colorimetric MTS assays (Promega, Madison, WI, USA) were performed as described [21]. Briefly, RLECs $\left(5 \times 10^{3}\right)$ were cultured in 96-well plates for $120 \mathrm{hrs}$ in DMEM and 5\% FBS; $5.5 \mathrm{mM}$ and $55 \mathrm{mM}$ D-glucose or $55 \mathrm{mM}$ D-mannitol; and $50 \mu \mathrm{g} / \mathrm{mL}$ purified honey or 5 or $50 \mu \mathrm{g} / \mathrm{mL}$ propolis. To each well was added 3-(4,5-dimethylthiazol-2-yl)-5-(3-carboxymethoxyphenyl)-2-(4-sulfophenyl)-2H-tetrazolium salt (MTS) for $4 \mathrm{hrs}$. In this assay, MTS is reduced to a water soluble formazan salt when added to medium containing viable cells, with this reduction determined by measuring absorbance at $490 \mathrm{~nm}$ with a microplate reader. Results were normalized relative to the absorbance of untreated control(s).

2.4. Animals. All animal experiments were approved by the Committee of Animal Research at Kanazawa Medical University (Permission number: 2013-88) and were conducted in accordance with the National Institutes of Health Guide for the Care and Use of Laboratory Animals, the recommendations of the Association for Research in Vision and Ophthalmology (ARVO) Statement on the Use of Animals in Ophthalmic and Vision Research, and the Institutional Guidelines for Laboratory Animals of Kanazawa Medical University.

Seven-week-old female Sprague-Dawley (SD) albino female rats were obtained from Sankyo Labo Service Corporation Inc. (Toyama, Japan). Purified honey and 30\% water soluble Brazilian propolis were supplied by Yamada Bee Farm Corporation (Okayama, Japan). Prior to treatment, all rats were given ad libitum access to regular chow (Oriental Yeast, Osaka, Japan). Rats were subsequently fed $0.6 \mathrm{~g} / \mathrm{kg}$ purified honey $(n=15), 0.1 \mathrm{~g} / \mathrm{kg}$ propolis $(n=10)$, or $0.6 \mathrm{~g} / \mathrm{kg}$ propolis $(n=10)$ every day for 1 week. To induce sugar cataracts, these rats were given ad libitum access to $15 \%$ or $25 \%$ Dgalactose mixed with regular chow (Oriental Yeast), as well as being continued on $0.6 \mathrm{~g} / \mathrm{kg} /$ day purified honey, $0.1 \mathrm{~g} / \mathrm{kg} /$ day propolis, or $0.6 \mathrm{~g} / \mathrm{kg} / \mathrm{day}$ propolis, for 3 weeks. Control rats were allowed ad libitum access to regular chow, as well as being continued on $0.6 \mathrm{~g} / \mathrm{kg} /$ day purified honey, for 3 weeks. The rats were subsequently sacrificed and lenses from the right eye of each were carefully removed and photographed using a stereomicroscope under dark-field illumination (Zeiss, Stemi DV4, Jena, Germany). The density of opacity was analyzed using MultiGauge Software (Fuji Film, Tokyo, Japan). Left eyes were processed for paraffin sectioning, stained with hematoxylin and eosin (H\&E) and examined histologically.

2.5. Statistical Analysis. The results are reported as means \pm standard deviation and were analyzed statistically using ANOVA with Fisher's test.

\section{Results}

3.1. Effect of Propolis on High-Glucose-Induced ROS Production and Cell Survival. To determine if propolis could inhibit high-glucose-induced ROS and reduced survival of RLECs cultured in vitro, RLECs cultured in DMEM containing $5.5 \mathrm{mM}$ and $55 \mathrm{mM}$ D-glucose or $55 \mathrm{mM} \mathrm{D}$-mannitol (Figure 1) were treated with 5 or $50 \mu \mathrm{g} / \mathrm{mL}$ propolis or 5 or $50 \mu \mathrm{g} / \mathrm{mL}$ purified honey. Cell viability assays showed that culture with $50 \mathrm{mM}$ glucose significantly reduced cell survival but that the addition to these cells of 5 or $50 \mu \mathrm{g} / \mathrm{mL}$ propolis significantly enhanced their viability, more so than that of RLECs cultured with $50 \mathrm{mM}$ glucose and treated with 


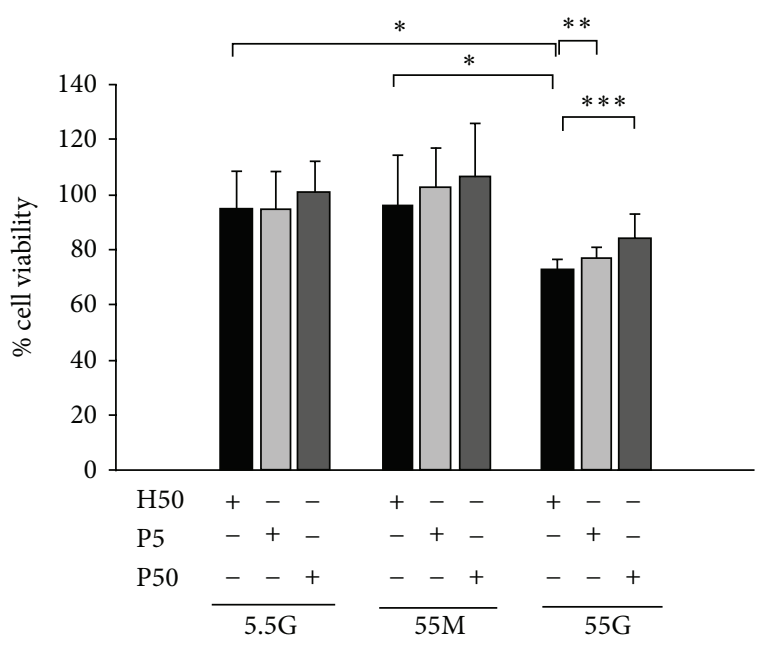

(a)

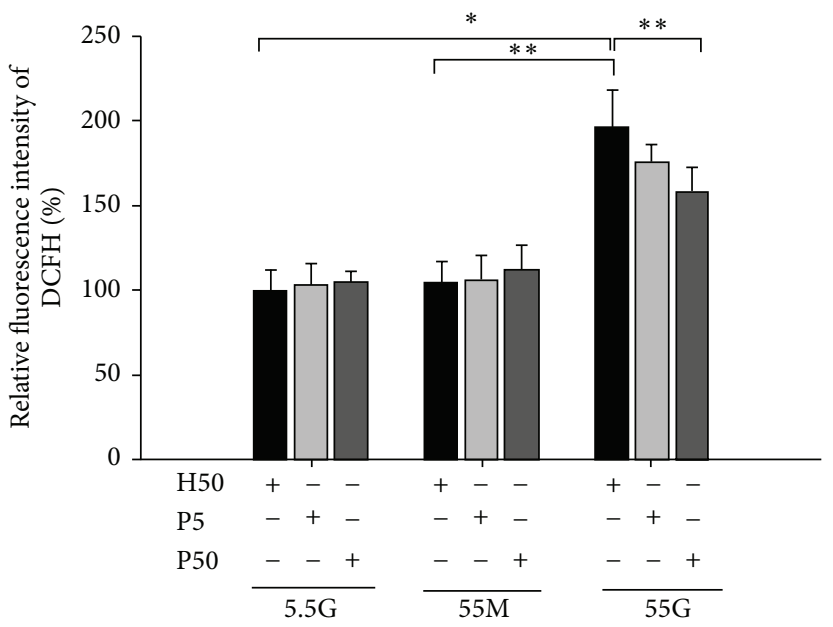

(b)

FIGURE 1: Effect of propolis on the viability and ROS production of cultured RLECs. Effect of propolis on intracellular ROS production and survival of RLECs following high glucose stress. Honey $(50 \mu \mathrm{g} / \mathrm{mL} ; \mathrm{H} 50)$ or propolis ( $5 \mathrm{or} 50 \mu \mathrm{g} / \mathrm{mL}$; 5 or P50) was added to RLECs cultured with 5.5 or $55 \mathrm{mM}$ D-glucose or with $55 \mathrm{mM} \mathrm{D}$-mannitol as osmotic control; 120 hrs later, ROS levels were measured using H2-DCFH-DA assay (a) and cell viability was estimated using colorimetric MTS assay (b). Results shown are the mean \pm SD of three experiments. Asterisks denote statistically significant differences. (a) ${ }^{*} P<0.009,{ }^{* *} P<0.05$, and ${ }^{* * *} P<0.002$. (b) ${ }^{*} P<0.0000001$ and ${ }^{* *} P<0.04$.

TABLE 1: Effect of water soluble propolis treatment on body weight in rats with galactose-feeding.

\begin{tabular}{lcc}
\hline Groups & $0 \mathrm{~W}(\mathrm{~g})$ & $3 \mathrm{~W}(\mathrm{~g})$ \\
\hline $\mathrm{C}+\mathrm{H} 0.6$ & $107.800 \pm 11.432$ & $200.400 \pm 4.159$ \\
$\mathrm{G} 15+\mathrm{H} 0.6$ & $102.800 \pm 10.208$ & $196.200 \pm 10.803$ \\
$\mathrm{G} 15+\mathrm{P} 0.1$ & $109.600 \pm 6.878$ & $199.200 \pm 10.450$ \\
$\mathrm{G} 15+$ P0.6 & $114.600 \pm 9.290$ & $192.200 \pm 10.085$ \\
G25 + H0.6 & $106.800 \pm 6.340$ & $192.600 \pm 8.264$ \\
G25 + P0.1 & $104.400 \pm 5.727$ & $188.800 \pm 5.762$ \\
G25 + P0.6 $^{*}$ & $110.400 \pm 9.762$ & $189.400 \pm 6.804$ \\
\hline
\end{tabular}

All results are expressed as the means \pm standard deviations.

C, control diet; G15, diet containing 15\% galactose; G25, diet containing $25 \%$ galactose; $\mathrm{H} 0.6$, administration of $0.6 \mathrm{~g} / \mathrm{kg} /$ day honey; P0.1, administration of $0.1 \mathrm{~g} / \mathrm{kg} /$ day propolis; $\mathrm{P} 0.6$, administration of $0.6 \mathrm{~g} / \mathrm{kg} /$ day propolis. ${ }^{*} \mathrm{P}<$ 0.02 .

$50 \mu \mathrm{g} / \mathrm{mL}$ honey (Figure 1(a)). Quantitation of ROS levels using H2-DCF-DA showed increased ROS levels in RLECs treated with $50 \mathrm{mM}$ glucose (Figure 1(b)), whereas the addition to these cells of 5 or $50 \mu \mathrm{g} / \mathrm{mL}$ propolis resulted in significantly lower ROS levels than the addition of $50 \mu \mathrm{g} / \mathrm{mL}$ honey (Figure 1(b)).

3.2. Animals and Their Characteristics. Table 1 shows the body weight of normal (control) rats and rats fed $15 \%$ or $25 \%$ galactose in the presence or absence of 0.1 or $0.6 \mathrm{~g} / \mathrm{kg} / \mathrm{day}$ water soluble propolis or $0.6 \mathrm{~g} / \mathrm{kg} /$ day honey. Although body weights did not differ significantly at the beginning of propolis or honey administration $(P>0.05)$, they increased in all three groups after 3 weeks (Table 1). Body weights of rats fed $25 \%$ galactose plus 0.1 or $0.6 \mathrm{~g} / \mathrm{kg} /$ day propolis for 3 weeks were significantly lower than the body weights of control rats fed $0.6 \mathrm{~g} / \mathrm{kg} /$ day honey $(P<0.02)$. This reduction was due to galactose, as body weights were similar in rats fed $25 \%$ galactose plus $0.1 \mathrm{~g} / \mathrm{kg} /$ day honey or 0.1 or $0.6 \mathrm{~g} / \mathrm{kg} /$ day propolis.

3.3. Propolis Inhibition of Sugar Cataracts. To determine if propolis was effective in delaying or preventing cataract progression or formation, lens opacification was analyzed in propolis- and honey-treated rats. Cortical and supranuclear opacity were observed in rats fed $15 \%$ and $25 \%$ galactose, with the severity of lens opacity being greater in rats fed $25 \%$ galactose (Figure 2(a)). Administration of $0.6 \mathrm{~g} / \mathrm{kg} /$ day propolis significantly reduced lens opacity (Figures 2(a) and 2(b)), indicating that water soluble propolis inhibits sugar-induced cataractogenesis in rats.

Histopathological analysis showed no detectable histological changes in the lenses of rats fed a control diet with $0.6 \mathrm{~g} / \mathrm{kg} /$ day honey (Figure 3). However, some peripheral opacity was observed in the equatorial and cortical regions of rats fed $15 \%$ galactose plus $0.6 \mathrm{~g} / \mathrm{kg} /$ day honey. Swelling of lens fibers was reduced in rats fed $15 \%$ galactose plus $0.1 \mathrm{~g} / \mathrm{kg} /$ day propolis and was significantly inhibited in rats fed $15 \%$ galactose plus $0.6 \mathrm{~g} / \mathrm{kg} /$ day propolis, with the latter also showing small vacuole formation between lens fibers. Rats fed $25 \%$ galactose plus $0.6 \mathrm{~g} / \mathrm{kg} /$ day honey showed progression of lens swelling, with deeper lesions and liquefaction of the cortex. Administration of $0.6 \mathrm{~g} / \mathrm{kg} /$ day propolis reduced lens fiber swelling in rats fed $25 \%$ galactose, whereas administration of $0.1 \mathrm{~g} / \mathrm{kg} /$ day propolis did not.

\section{Discussion}

This study evaluated the ability of water soluble propolis to inhibit or delay the development of sugar- and oxidative stress-induced cataractogenesis. We found that propolis could inhibit high-glucose-induced ROS generation and cell 

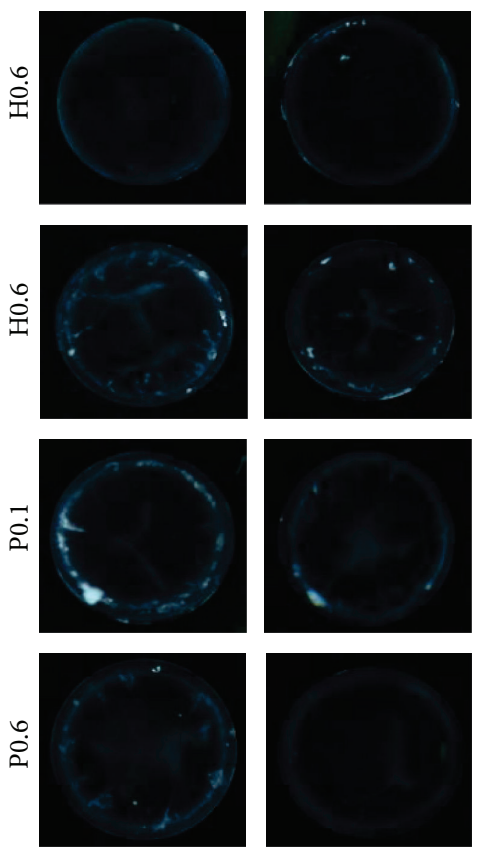

(a)
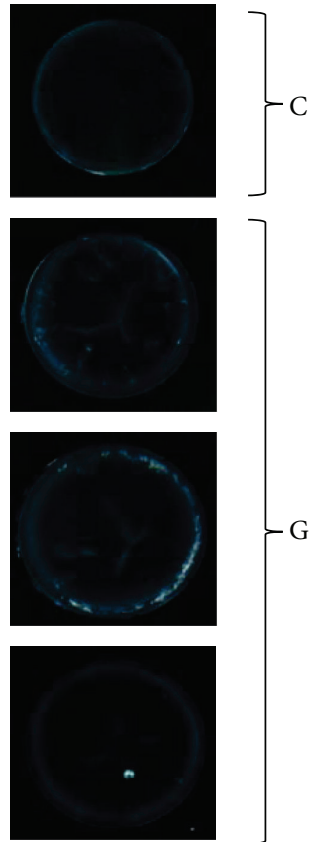
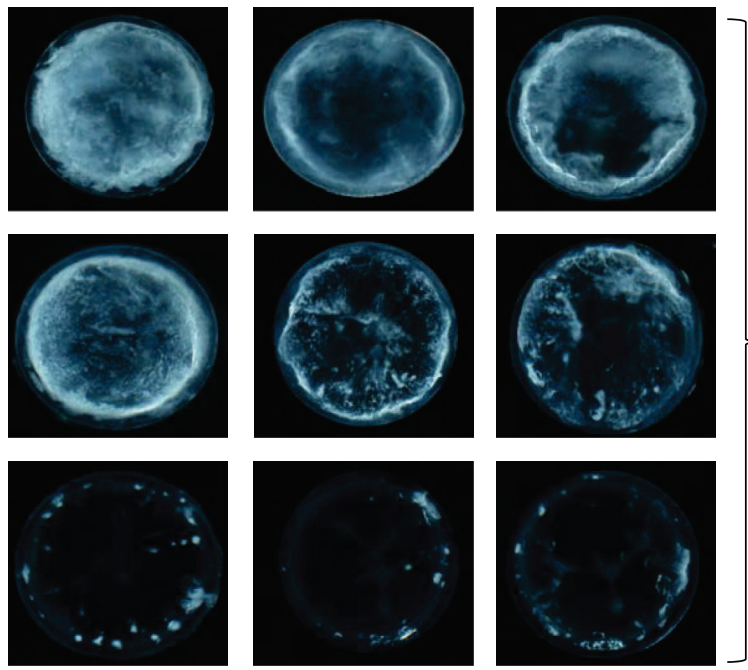

(b)

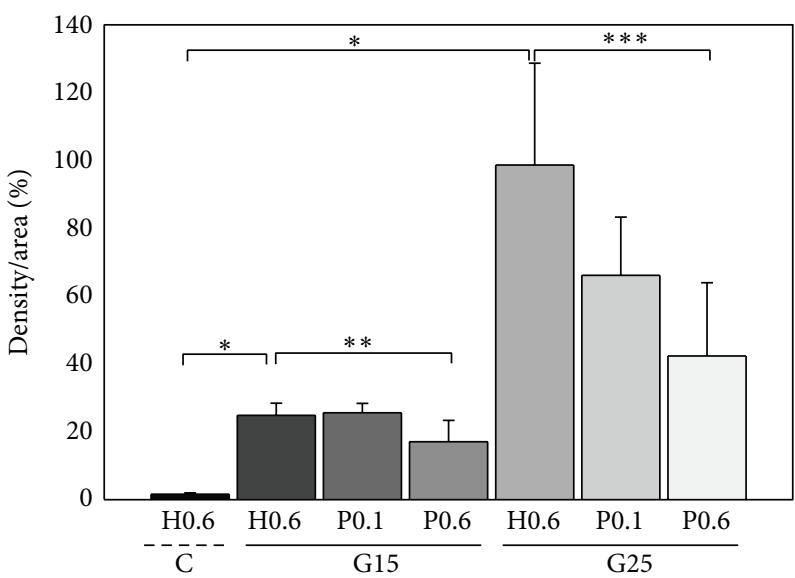

(c)

FIGURE 2: Effect of water soluble propolis on lens opacity in rats fed a high galactose diet. Rats in each group were given ad libitum access to $15 \%$ or $25 \%$ D-galactose mixed with regular chow, as well as being continued on $0.6 \mathrm{~g} / \mathrm{kg} / \mathrm{day}$ purified honey, $0.1 \mathrm{~g} / \mathrm{kg} / \mathrm{day}$ propolis, or $0.6 \mathrm{~g} / \mathrm{kg} / \mathrm{day}$ propolis, for 3 weeks. Control rats were allowed ad libitum access to regular chow, as well as being continued on $0.6 \mathrm{~g} / \mathrm{kg} / \mathrm{day}$ purified honey, for 3 weeks. Propolis suppressed lens opacity in rats fed (a) $15 \%$ and (b) $25 \%$ galactose. (c) Densitometry shows that oral intake of propolis $(0.6 \mathrm{~g} / \mathrm{kg})$ significantly suppressed lens opacity in galactose-fed rats. Results shown are the mean \pm SD of three experiments. Asterisks denote statistically significant differences. ${ }^{*} P<0.000006 ;{ }^{* *} P<0.05 ;{ }^{* * *} P<0.01$.

death in cultured RLECs. We also found that propolis inhibited the formation of galactose-induced cataracts. The polyol pathway has been reported to be responsible for generating osmotic stress and oxidative stress $[10,11,22,23]$, with antioxidant treatment postponing the progression of cataracts in diabetic rats [24], thus demonstrating that oxidative stress is a major factor in the chronic development of diabetic cataracts. We have reported that hyperglycemic apoptosis of LECs involves polyol pathway-dependent osmotic stress and oxidative stress $[11,25]$. AR upregulation in diabetic cataracts induces apoptosis, demonstrating the therapeutic potential of
Prdx6 as an antioxidant in the prevention and control of hyperglycemia-induced complications [25].

Propolis, a resinous substance collected by honeybees from buds and crevices in the bark of various trees, contains more than 200 different constituents, including active organic compounds, such as artepillin C (APC), benzoic acids, flavonoids, caffeoylquinic acids (CAs), cinnamic acid, and derivatives of coumaric acid [26,27]. CAs were shown to inhibit rat AR activity in vitro and the formation of advanced glycation end products and associated protein cross-linking; moreover, administration of CAs prevented the development 


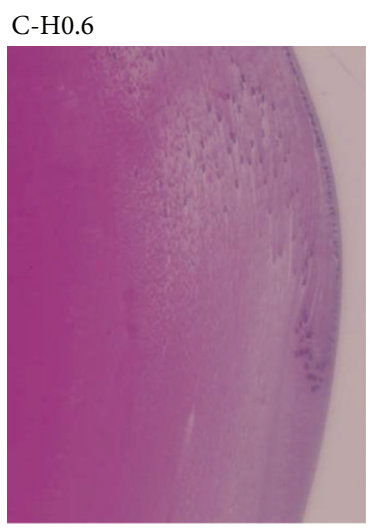

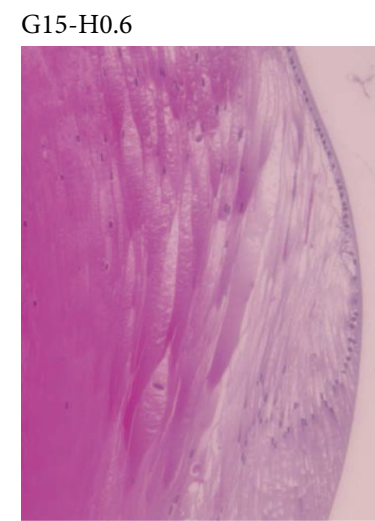

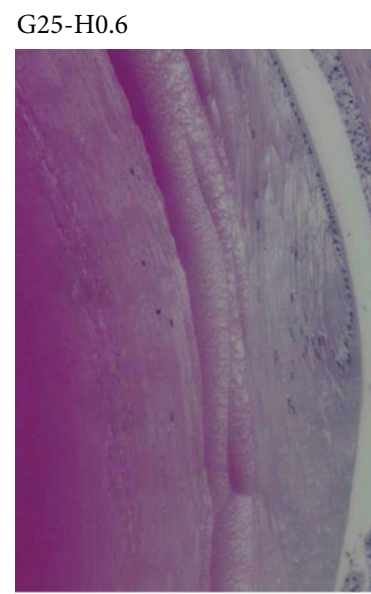

G15-P0.1

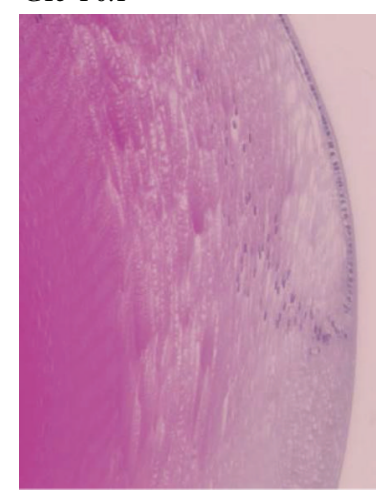

G25-P0.1

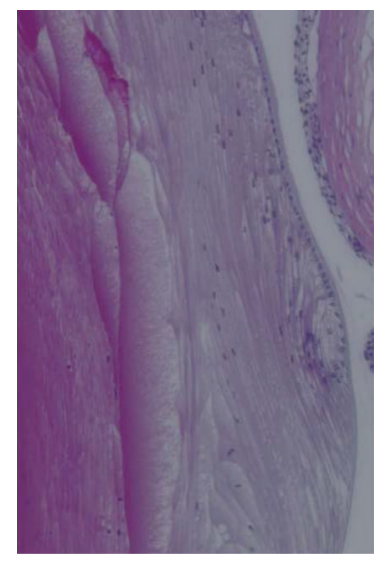

G15-P0.6

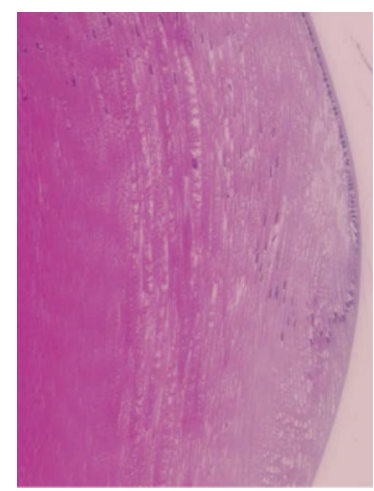

G25-P0.6

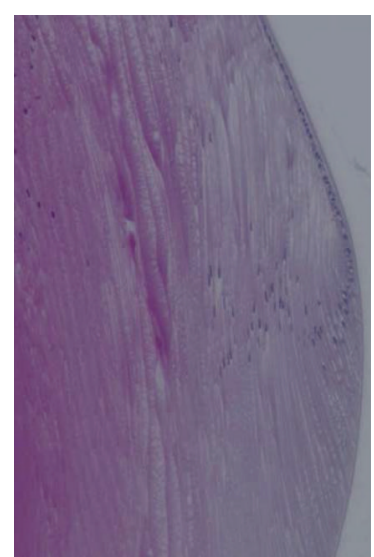

FIGURE 3: Histological images of sugar cataract formation in rats fed diets containing $15 \%$ and $25 \%$ galactose with/without propolis treatment. Rats fed a normal diet plus $0.6 \mathrm{~g} / \mathrm{kg} /$ day honey showed no cataractous changes ((a) and (b)). Three weeks after feeding with $15 \%$ galactose plus $0.6 \mathrm{~g} / \mathrm{kg} /$ day honey, lens fiber swelling was observed in the anterior and equatorial regions, whereas feeding with $25 \%$ galactose plus $0.6 \mathrm{~g} / \mathrm{kg} /$ day honey resulted in marked swelling and liquefaction of the cortical fibers in the equatorial region of the lenses. These histological changes were suppressed by treatment with $0.6 \mathrm{~g} / \mathrm{kg} /$ day propolis.

of sugar cataracts by inhibiting AR activity [28, 29]. Natural flavonoids, such as quercetin, have antioxidant activity and inhibit AR and advanced glycation, suggesting that they may prevent the formation of diabetic cataracts [30,31]. Although the pure form of each component of propolis should be examined for protection against sugar cataracts and highglucose-induced ROS production, the ability of propolis to inhibit sugar cataracts in this study may have been due to the ability of CAs and flavonoids to inhibit AR activity. Efforts are needed to identify the constituents of propolis most effective in protecting against ROS and sugar cataracts.

Treatment with 0.1 or $0.6 \mathrm{~g} / \mathrm{kg} /$ day propolis significantly reduced the body weights of rats fed $25 \%$ galactose, compared with control rats treated with $0.6 \mathrm{~g} / \mathrm{kg} /$ day honey; however, there was no difference in body weight between control rats and $25 \%$ galactose-fed rats treated with honey $0.6 \mathrm{~g} / \mathrm{kg} / \mathrm{day} /$ honey. Treatment of obese C57BL/6N mice with propolis extract was found to reduce body weight, the serum concentrations of nonesterified fatty acids, and lipid accumulation in the liver [32]. However, as $25 \%$ galactose itself may have reduced body weight, we could not conclude that propolis had an effect on body weight in galactose-fed rats.
In conclusion, this study showed that soluble green propolis can inhibit galactose-induced cataracts in rats. Propolis may reduce oxidative stress and may inhibit the polyol pathway, thus delaying and/or blunting the formation of sugar-induced cataracts.

\section{Competing Interests}

The authors declare that there are no competing interests regarding the publication of this paper.

\section{Acknowledgments}

Grants were provided by the National Eye Institute (NIH) (EY024589) (to Dhirendra P. Singh) and 2012 Yamada Research Grant was provided to Etsuko Kiyokawa.

\section{References}

[1] P. F. Kador, Y. Akagi, and J. H. Kinoshita, "The effect of aldose reductase and its inhibition on sugar cataract formation," Metabolism, vol. 35, no. 4, supplement 1, pp. 15-19, 1986. 
[2] J. H. Kinoshita, "Mechanisms initiating cataract formation. Proctor lecture," Investigative Ophthalmology, vol. 13, no. 10, pp. 713-724, 1974.

[3] J. H. Kinoshita, P. Kador, and M. Catiles, "Aldose reductase in diabetic cataracts," The Journal of the American Medical Association, vol. 246, no. 3, pp. 257-261, 1981.

[4] A. Y. W. Lee, S. K. Chung, and S. S. M. Chung, "Demonstration that polyol accumulation is responsible for diabetic cataract by the use of transgenic mice expressing the aldose reductase gene in the lens," Proceedings of the National Academy of Sciences of the United States of America, vol. 92, no. 7, pp. 2780-2784, 1995.

[5] S. P. Wolff, Z. Y. Jiang, and J. V. Hunt, "Protein glycation and oxidative stress in diabetes mellitus and ageing," Free Radical Biology and Medicine, vol. 10, no. 5, pp. 339-352, 1991.

[6] M. F. Lou, J. E. Dickerson Jr., R. Garadi, and B. M. York Jr., "Glutathione depletion in the lens of galactosemic and diabetic rats," Experimental Eye Research, vol. 46, no. 4, pp. 517-530, 1988.

[7] P. F. Kador, J. H. Kinoshita, D. R. Brittain, D. J. Mirrlees, C. M. Sennitt, and D. Stribling, "Purified rat lens aldose reductase. Polyol production in vitro and its inhibition by aldose reductase inhibitors," Biochemical Journal, vol. 240, no. 1, pp. 233-237, 1986.

[8] D. Dvornik, N. Simard-Duquesne, M. Krami et al., "Polyol accumulation in galactosemic and diabetic rats: control by an aldose reductase inhibitor," Science, vol. 182, no. 4117, pp. 1146-1148, 1973.

[9] J. H. Kinoshita, "Cataracts in galactosemia. The Jonas S. Friedenwald Memorial Lecture," Investigative Ophthalmology, vol. 4, no. 5, pp. 786-799, 1965.

[10] P. A. Barnett, R. G. Gonzalez, L. T. Chylack Jr., and H.-M. Cheng, "The effect of oxidation on sorbitol pathway kinetics," Diabetes, vol. 35, no. 4, pp. 426-432, 1986.

[11] E. Kubo, N. Miyoshi, M. Fukuda, and Y. Akagi, "Cataract formation through the polyol pathway is associated with free radical production," Experimental Eye Research, vol. 68, no. 4, pp. 457-464, 1999.

[12] M. L. Mulhern, C. J. Madson, A. Danford, K. Ikesugi, P. F. Kador, and T. Shinohara, "The unfolded protein response in lens epithelial cells from galactosemic rat lenses," Investigative Ophthalmology and Visual Science, vol. 47, no. 9, pp. 3951-3959, 2006.

[13] T. Nishikawa, D. Edelstein, X. L. Du et al., "Normalizing mitochondrial superoxide production blocks three pathways of hyperglycaemic damage," Nature, vol. 404, no. 6779, pp. 787790, 2000.

[14] T. Sakurai and S. Tsuchiya, "Superoxide production from nonenzymatically glycated protein," FEBS Letters, vol. 236, no. 2, pp. 406-410, 1988.

[15] T. Inoguchi, T. Sonta, H. Tsubouchi et al., "Protein kinase Cdependent increase in reactive oxygen species (ROS) production in vascular tissues of diabetes: role of vascular $\mathrm{NAD}(\mathrm{P}) \mathrm{H}$ oxidase," Journal of the American Society of Nephrology, vol. 14, supplement 3, no. 8, pp. S227-S232, 2003.

[16] S. S. M. Chung, E. C. M. Ho, K. S. L. Lam, and S. K. Chung, "Contribution of polyol pathway to diabetes-induced oxidative stress," Journal of the American Society of Nephrology, vol. 14, no. 3, pp. S233-S236, 2003.

[17] M. Kanwar, P.-S. Chan, T. S. Kern, and R. A. Kowluru, "Oxidative damage in the retinal mitochondria of diabetic mice: possible protection by superoxide dismutase," Investigative Ophthalmology and Visual Science, vol. 48, no. 8, pp. 3805-3811, 2007.
[18] S. Akyol, Z. Ginis, F. Armutcu, G. Ozturk, M. R. Yigitoglu, and O. Akyol, "The potential usage of caffeic acid phenethyl ester (CAPE) against chemotherapy-induced and radiotherapyinduced toxicity," Cell Biochemistry and Function, vol. 30, no. 5, pp. 438-443, 2012.

[19] M. T. Al-Hariri, "Propolis and its direct and indirect hypoglycemic effect," Journal of Family and Community Medicine, vol. 18, no. 3, pp. 152-154, 2011.

[20] T. Matsui, S. Ebuchi, T. Fujise et al., "Strong antihyperglycemic effects of water-soluble fraction of Brazilian propolis and its bioactive constituent, 3,4,5-tri-O-caffeoylquinic acid," Biological and Pharmaceutical Bulletin, vol. 27, no. 11, pp. 1797-1803, 2004.

[21] E. Kubo, N. Fatma, Y. Akagi, D. R. Beier, S. P. Singh, and D. P. Singh, "TAT-mediated PRDX6 protein transduction protects against eye lens epithelial cell death and delays lens opacity," American Journal of Physiology-Cell Physiology, vol. 294, no. 3, pp. C842-C855, 2008.

[22] A. Y. W. Lee and S. S. M. Chung, "Contributions of polyol pathway to oxidative stress in diabetic cataract," The FASEB Journal, vol. 13, no. 1, pp. 23-30, 1999.

[23] N. H. Ansari, L. Wang, A. A. Erwin, and D. F. Church, "Glucosedependent formation of free radical species in lens homogenate," Biochemical and Molecular Medicine, vol. 59, no. 1, pp. 6871, 1996.

[24] S. K. Srivastava and N. H. Ansari, "Prevention of sugar-induced cataractogenesis in rats by butylated hydroxytoluene," Diabetes, vol. 37, no. 11, pp. 1505-1508, 1988.

[25] E. Kubo, T. Urakami, N. Fatma, Y. Akagi, and D. P. Singh, "Polyol pathway-dependent osmotic and oxidative stresses in aldose reductase-mediated apoptosis in human lens epithelial cells: role of AOP2," Biochemical and Biophysical Research Communications, vol. 314, no. 4, pp. 1050-1056, 2004.

[26] R. Christov, B. Trusheva, M. Popova, V. Bankova, and M. Bertrand, "Chemical composition of propolis from Canada, its antiradical activity and plant origin," Natural Product Research, vol. 19, no. 7, pp. 673-678, 2005.

[27] V. Bankova, "Recent trends and important developments in propolis research," Evidence-Based Complementary and Alternative Medicine, vol. 2, no. 1, pp. 29-32, 2005.

[28] C.-S. Kim, J. Kim, Y. M. Lee, E. Sohn, K. Jo, and J. S. Kim, "Inhibitory effects of chlorogenic acid on aldose reductase activity in vitro and cataractogenesis in galactose-fed rats," Archives of Pharmacal Research, vol. 34, no. 5, pp. 847-852, 2011.

[29] J. Kim, I.-H. Jeong, C.-S. Kim, Y. M. Lee, J. M. Kim, and J. S. Kim, "Chlorogenic acid inhibits the formation of advanced glycation end products and associated protein cross-linking," Archives of Pharmacal Research, vol. 34, no. 3, pp. 495-500, 2011.

[30] M. Stefek and C. Karasu, "Eye lens in aging and diabetes: effect of quercetin," Rejuvenation Research, vol. 14, no. 5, pp. 525-534, 2011.

[31] S. D. Varma, I. Mikuni, and J. H. Kinoshita, "Flavonoids as inhibitors of lens aldose reductase," Science, vol. 188, no. 4194, pp. 1215-1216, 1975.

[32] S. Koya-Miyata, N. Arai, A. Mizote et al., "Propolis prevents diet-induced hyperlipidemia and mitigates weight gain in dietinduced obesity in mice," Biological and Pharmaceutical Bulletin, vol. 32, no. 12, pp. 2022-2028, 2009. 


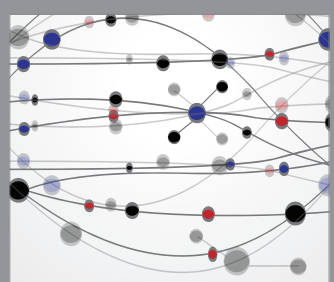

The Scientific World Journal
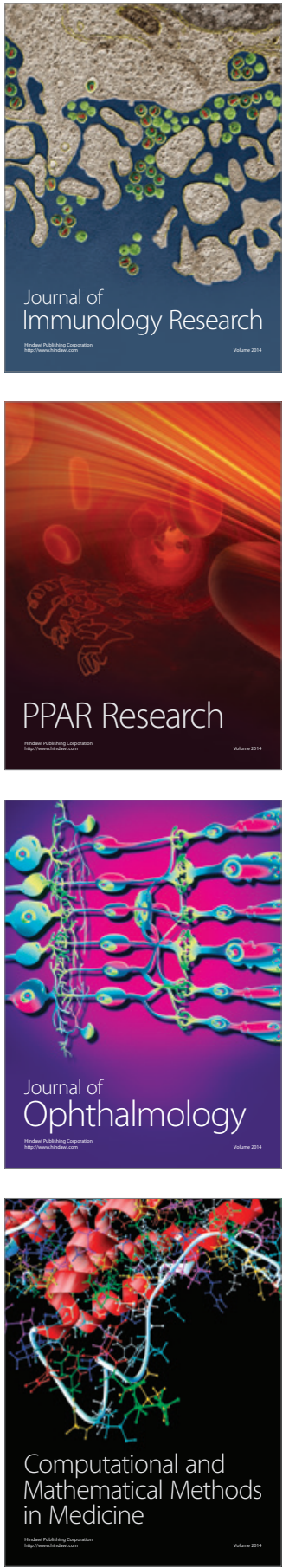

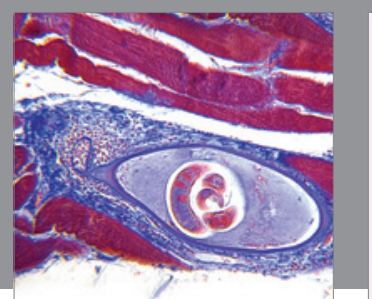

Gastroenterology Research and Practice

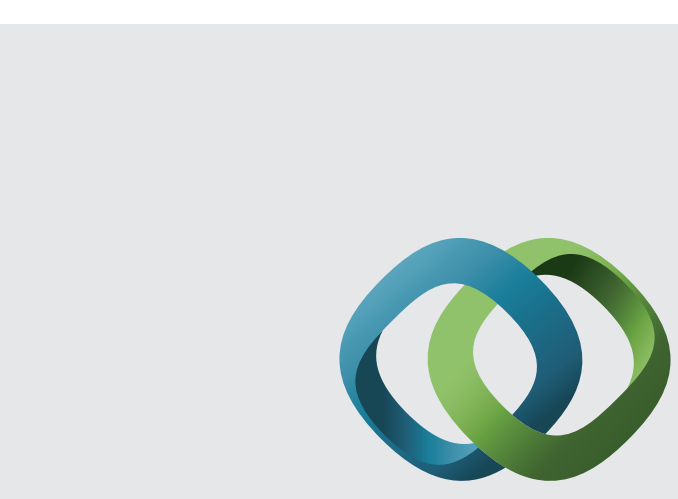

\section{Hindawi}

Submit your manuscripts at

http://www.hindawi.com
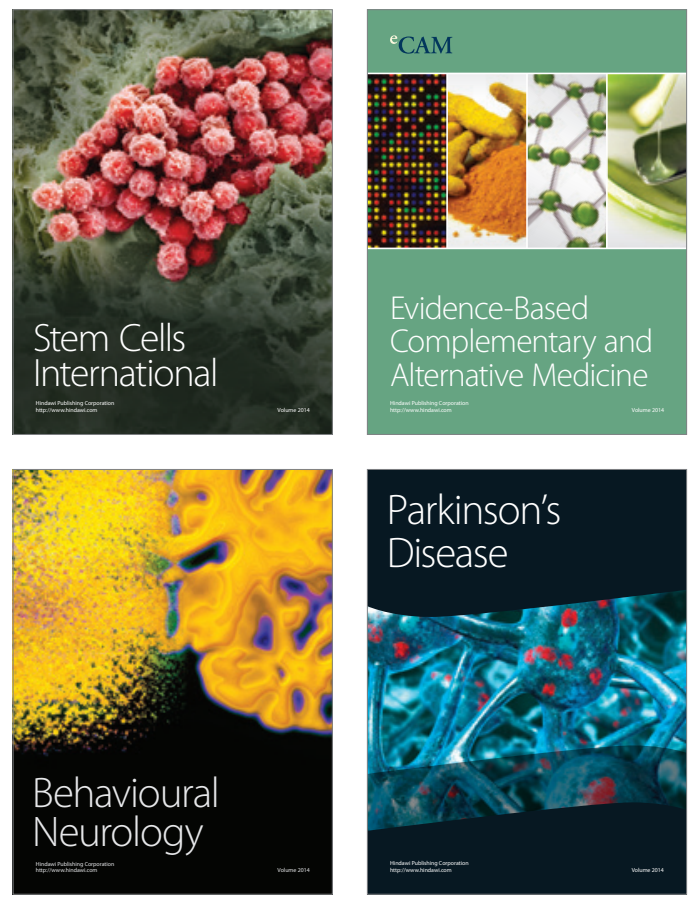
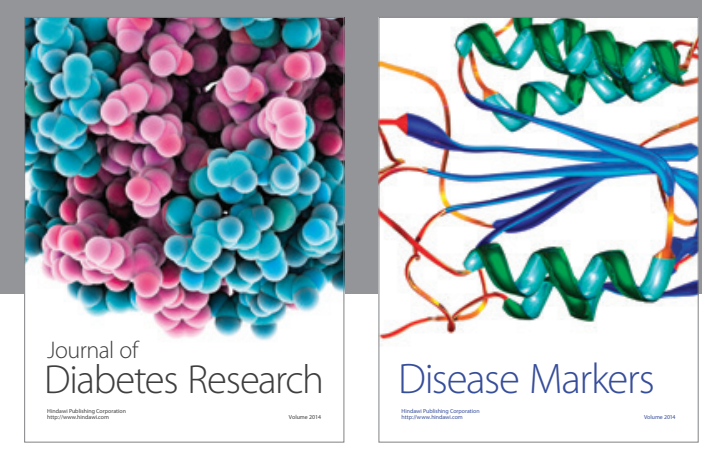

Disease Markers
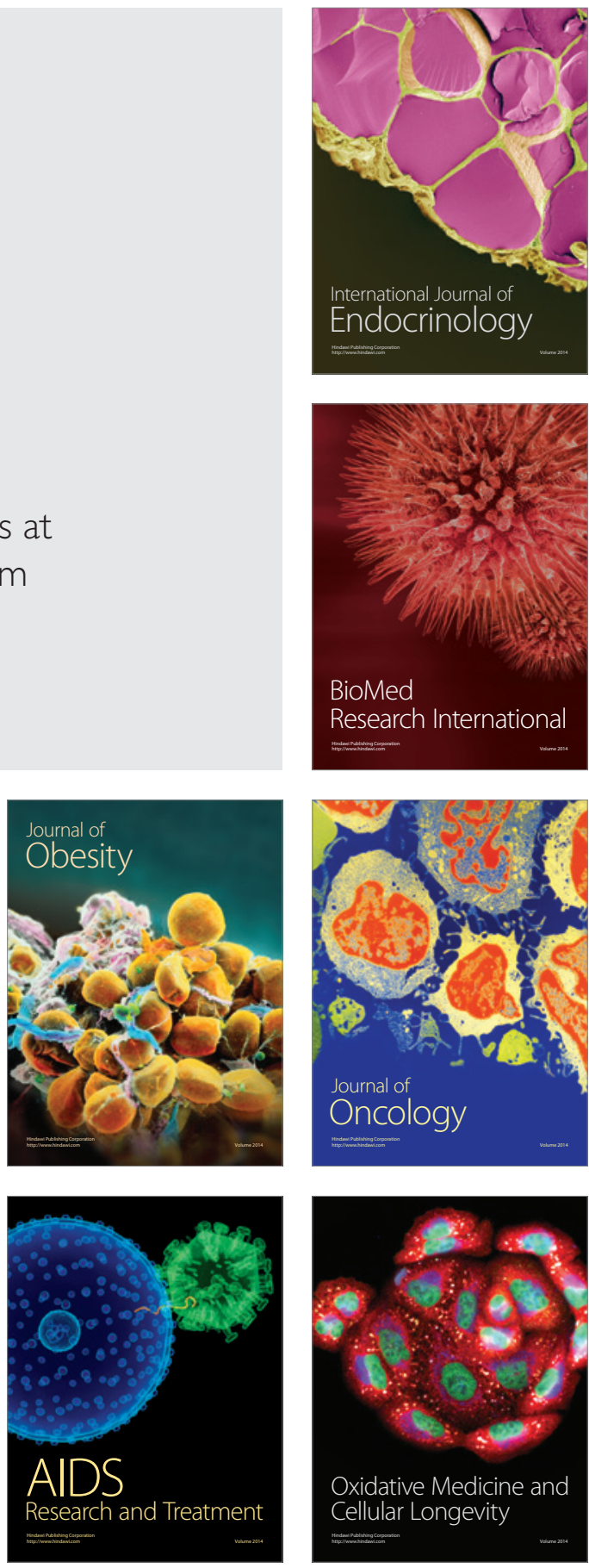